\title{
Sperm ultrastructure in three different families of weakly electric fishes (Teleostei: Gymnotiformes)
}

\author{
Júlia Giora ${ }^{1}$ and John R. Burns ${ }^{2}$
}

This study presents details of sperm ultrastructure for Gymnotus aff. carapo (Gymnotidae), Eigenmannia trilineata (Sternopygidae), and three Brachyhypopomus species (B. draco, B. bombilla, and B. gauderio - Hypopomidae) from southern Brazil. Differences were found among the representatives of the different families. For example, nuclear rotation was present in E. trilineata and in the Brachyhypopomus species, but absent in Gymnotus aff. carapo, and the presence of flagellar fins was only observed in E. trilineata. Some intraspecific variations could also be noticed among the Brachyhypopomus species analyzed. Most of the characters found in the spermatozoa of the species studied herein are shared with species of Gymnotiformes previously analyzed.

Este estudo apresenta detalhes sobre a ultraestrutura do espermatozoide de Gymnotus aff. carapo (Gymnotidae), Eigenmannia trilineata (Sternopygidae), e três espécies de Brachyhypopomus (B. draco, B. bombilla, e B. gauderio - Hypopomidae) do sul do Brasil. Diferenças foram encontradas entre os representantes das diferentes famílias, como por exemplo a presença de rotação nuclear em E. trilineata e nas espécies de Brachyhypopomus e a ausência em $G$. aff. carapo, e a presença de aletas laterais no flagelo observada somente em E. trilineata. Algumas variações intraespecíficas também puderam ser registradas entre as espécies de Brachyhypopomus analisadas. A maioria das características encontradas nos espermatozoides das espécies aqui analisadas são compartilhadas com as demais espécies de Gymnotifomes previamente analisadas.

Key words: Gymnotidae, Hypopomidae, Spermatozoa, Sternopygidae.

\section{Introduction}

The order Gymnotiformes is restricted to Neotropical freshwaters, from Guatemala to Argentina, and also on the Caribbean island of Trinidad (Mago-Leccia, 1978). The order is comprised of five families and 185 species (Eschmeyer \& Fong, 2011) and, although there are many hypotheses on the relationships among its families (Triques, 1993; Mago-Leccia, 1994; Alves-Gomes et al., 1995, Albert \& Crampton, 2005), they are still controversial.

According to Mattei (1991), since great structural diversity has been demonstrated for fish at all taxonomic levels, it has not been possible to construct spermatic models, even for monophyletic groups such as Actinopterygii or Teleostei. For this reason, results from sperm ultrastructure have provided valuable information on cellular modifications associated with reproductive habits and uncovered morphological characters useful in hypothesizing phylogenetic relationships (Baccetti, 1987; Baicere-Silva et al., 2011; Burns et al., 1998; Burns et al., 2002).

Ultrastructural studies on gymnotiform spermatozoa have been carried out on Apteronotus albifrons (Linnaeus, 1766) (cited as Sternarchus albifrons) (Jamieson,1991), Gymnotus cf. anguilaris Hoedeman, 1962 and Brachyhypopomus cf. pinnicaudatus (Hopkins, 1991) (França et al., 2007), and Rhamphichthys cf. hahni (Meinken, 1937), Eigenmannia cf. virescens (Valenciennes, 1842) and Apteronotus cf. albifrons (França et al., 2009). However, many questions remain and more studies are needed to better understand sperm evolution in the order Gymnotiformes (França, 2006). The purpose of the present study is to provide details of sperm ultrastructure in Gymnotus aff. carapo Linnaeus, 1758, Eigenmannia trilineata López \& Castello, 1966, and three Brachyhypopomus species (B. draco Giora, Malabarba \& Crampton, 2008, B. bombilla Loureiro \& Silva, 2006, and B. gauderio Giora \& Malabarba, 2009) from southern Brazil.

${ }^{1}$ Universidade Federal do Rio Grande do Sul, IB, Departamento de Zoologia, Av. Bento Gonçalves, 9500, bloco IV, prédio 43435, 91501 970 Porto Alegre, RS, Brazil.jugiora@hotmail.com

${ }^{2}$ George Washington University, Department of Biological Sciences, Washington, DC, USA, 20052. 


\section{Material and Methods}

The present study was conducted on adult males of Brachyhypopomus bombilla, Brachyhypopomus draco, Brachyhypopomus gauderio, Eigenmannia trilineata, and Gymnotus aff. carapo collected in Rio Grande do Sul State, southern Brazil. Brachyhypopomus draco, B. gauderio, and $G$. aff. carapo were collected at a flooded area near the arroio dos Ratos creek (29'57'31.9'"S 51'33'10.1'W), Charqueadas Municipality, laguna dos Patos drainage. Brachyhypopomus bombilla and E. trilineata were collected at a creek that is part of the rio Uruguay drainage $\left(30^{\circ} 12^{\prime} 42.8^{\prime \prime} \mathrm{S} 55^{\circ} 03^{\prime} 17.5^{\prime \prime} \mathrm{W}\right)$, near Rosário do Sul Municipality. The fishes were sacrificed by severing the spinal cord. Immediately afterwards, small pieces of testes were placed in modified Karnovsky's fixative (Ito \& Karnosvsky, 1968) and kept under refrigeration until the start of further processing. The fishes were deposited in the fish collection of the Universidade Federal do Rio Grande do Sul (Brachyhypopomus gauderio - UFRGS 9200; Brachyhypopomus bombilla - UFRGS 9284, Brachyhypopomus draco - UFRGS 6750, Eigenmannia trilineata - UFRGS 6635, Gymnotus aff. carapo - UFRGS 6859).

Testes were dehydrated in an ethanol series and criticalpoint dried for scanning electron microscopy (SEM). The dried tissue was then attached to stubs with carbon double-stick tape and teased apart with needles. The sample was sputtercoated with carbon and gold and viewed in a LEO 1430VP scanning electron microscope. For transmission electron microscopy (TEM), testes were cut into small pieces $\left( \pm 1 \mathrm{~mm}^{3}\right)$, rinsed in phosphate buffer and post-fixed in $1 \%$ osmium tetroxide in phosphate buffer. Afterwards testes were rinsed in phosphate buffer, dehydrated in an ethanol series, infiltrated, and embedded in Araldite 502. Ultrathin sections were cut on a Sorvall MT5000 ultramicrotome, mounted on grids, and stained with aqueous uranyl acetate and lead citrate. Sections were examined with a JEOL JEM 1200 transmission electron microscope.

\section{Results}

\section{Spermatozoa of Brachyhypopomus draco, Brachyhypopomus bombilla and Brachyhypopomus gauderio - Hypopomidae.}

The spermatozoa of the three analyzed species are characterized by a well defined head, midpiece, and single flagellum. Both the head and nucleus tend to be spherical in $B$. draco (head, Fig. 1F; nucleus Fig. 1G-H-I), but ovoid in $B$. gauderio (head, Fig. 1A; nucleus, Fig. 1B-C) and B. bombilla (head, Fig. 1K; nucleus, Fig. 1M-N). Nuclear diameter is $1.0 \mu \mathrm{m}$ for $B$. draco; length and width nuclear measurements are $1.7 \mathrm{x}$ $2.8 \mu \mathrm{m}$ for $B$. gauderio and $0.9 \times 1.8 \mu \mathrm{m}$ for B. bombilla. Nuclear chromatin is condensed and granular in all three species, with extensive areas of lighter chromatin seen only in B. bombilla (Fig. 1M-N). All species undergo nuclear rotation. The proximal centriole is anterior, slightly lateral and perpendicular to the distal. Electron-dense material is associated with both centrioles.
The proximal centriole and most of the distal are contained within a deep nuclear fossa (Fig. 1C-I-M). Only in B. gauderio does the fossa branch extensively throughout the nucleus (Fig. 1B). The midpiece contains several elongate mitochondria and a large number of vesicles, some of which contain stainable material (Fig. 1B-D-G-H-M). An open cytoplasmic canal is only observed immediately posterior to the centriolar complex in $B$. gauderio (Fig. 1C) and B. draco (Fig. 1I) but this may close more posteriorly. An open cytoplasmic canal is not apparent in B. bombilla. An area of more organized membranous structures is only observed in the midpiece of $B$. draco (Fig. 1G-J). The flagellum has the classic $9+2$ microtubular pattern and does not show intratubular differentiation, both tubules of each peripheral doublet being electron-lucent (Fig 1E-J-L). The flagellar membrane does not have lateral projections or fins in any of the species. However, there is substantially more cytoplasm between the axoneme and flagellar membrane in $B$. bombilla (Fig. 1L).

\section{Spermatozoa of Gymnotus aff. carapo - Gymnotidae}

The spermatozoa of Gymnotus aff. carapo are comprised of a head (Fig. 2A) containing a spherical nucleus (Fig. 2C), a

Fig. 1. (next page) A-F-K: Spermatozoa of Brachyhypopomus gauderio, Brachyhypopomus draco, and Brachyhypopomus bombilla respectively $(\mathrm{SEM}), \mathrm{h}=$ sperm head, arrow $=$ flagellum, double arrow $=$ midpiece; B-C: Spermatozoa of $B$. gauderio in longitudinal section (TEM) showing ovoid nucleus (n), deep nuclear fossa (nf), centriolar arrangement ( $\mathrm{dc}=$ distal centriole, $\mathrm{pc}=$ proximal centriole), open cytoplasmatic canal (cc), and presence of vesicles (v) containing some electron-dense material, $\mathrm{f}=$ flagellum; $\mathbf{D}$ : Midpiece of spermatozoa of $B$. gauderio in cross section (TEM) showing cytoplasmatic canal (cc) and elongate mitochondrion (m); E: Flagella of spermatozoa of B. gauderio in cross section (TEM) showing electron-lucent tubules of each peripheral doublet (arrow); G-H-I: Spermatozoa of $B$. draco in longitudinal section (TEM) showing spherical nucleus $(\mathrm{n})$, centriolar arrangement $(\mathrm{dc}=$ distal centriole, $\mathrm{pc}=$ proximal centriole), open cytoplasmatic canal (cc), elongate mitochondria (m), and presence of vesicles (v) containing some electron-dense material and forming an organized membranous structure; J: Midpiece and flagellum of spermatozoa of $B$. draco in cross section (TEM) showing vesicles (v) forming an organized membranous structure, and electron-lucent tubules of each peripheral doublet (arrow); L: Flagella of spermatozoa of B. bombilla in longitudinal and cross section (TEM) showing electron-lucent tubules of each peripheral doublet (arrow), and cytoplasm located between axoneme (a) and flagellar membrane (asterisk); M-N: Spermatozoa of B. bombilla in longitudinal section (TEM) showing ovoid nucleus with extensive areas of lighter chromatin (n), centriolar arrangement $(\mathrm{dc}=$ distal centriole, $\mathrm{pc}=$ proximal centriole $)$, elongate mitochondria (m), and presence of vesicles (v) containing some electron-dense material. Scale bars $=1 \mu \mathrm{m}$. 


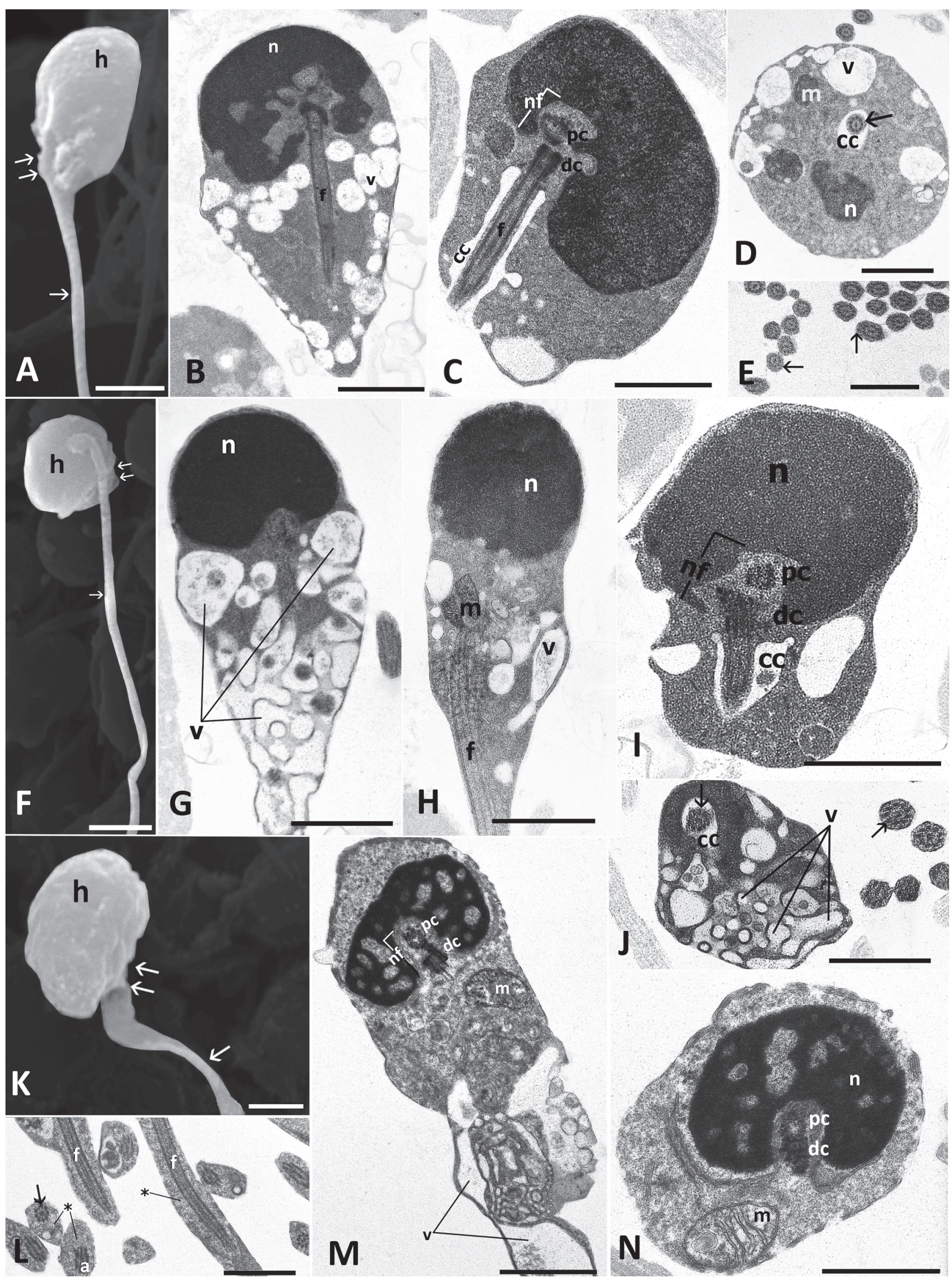


well defined midpiece (Fig. 2C-E) and a single flagellum (Fig. 2A-B-C-E). Nuclear diameter is approximately $1.9 \mu \mathrm{m}$. Nuclear chromatin is condensed and granular (Fig. 2B-C). The nucleus does not appear to undergo rotation during spermiogenesis, thus resulting in a centriolar complex and flagellum that are lateral to the nucleus (Fig. 2B-C). The nucleus is indented by a double, shallow, and strongly eccentric nuclear fossa (Fig. $2 \mathrm{~B})$. The proximal centriole is anterior and perpendicular to the distal centriole, both are associated with electron-dense spurs and other material, and both are located to one side of the nucleus completely outside the nuclear fossa (Fig. 2B-C). The midpiece contains spherical to elongate mitochondria irregularly distributed, and abundant vesicles, most of which are concentrated in the posterior portion of midpiece (Fig. 2C-E). Many of these vesicles are elongate and often contain electron-dense material. The midpiece also contains a short cytoplasmic canal immediately posterior to the distal centriole (Fig. 2B-E), but this appears to close more posteriorly. The single flagellum has a $9+2$ microtubular axoneme which does not show intratubular differentiation (Fig. 2D). The flagellum lacks lateral projections or fins (Fig. 2D). Some irregularly arranged accessory microtubules were present in the cytoplasm of the midpiece, but these were not evident on all micrographs.

\section{Spermatozoa of Eigenmannia trilineata - Sternopygidae}

The spermatozoa of Egenmannia trilineata are comprised of a spherical head (Fig. 3A) containing an ovoid nucleus (Fig. 1B), a distinct midpiece (Fig. 3B-E), and single flagellum (Fig. 3A-B). Nuclear length measured approximately $1.3 \mu \mathrm{m}$ and width $1.3 \mu \mathrm{m}$. The nucleus contains masses of electron-dense flocculent chromatin in a lighter matrix (Fig. 3B-E). Nuclear rotation takes place during spermiogenesis. The proximal centriole is anterior and perpendicular to the distal centriole and both centrioles are contained within a nuclear fossa (Fig. 3B). It was not possible to definitively identify a cytoplasmic collar in the region immediately posterior to the nucleus; however, more posteriorly a collar is lacking. The midpiece contains several elongate mitochondria (Fig. 3B-D-E) and relatively few vesicles (Fig. 3D-E). The flagellum has the usual $9+2$ microtubular arrangement with no intratubular differentiation (Fig. 3C-D). Along most of its length the flagellum has a pair of lateral projections or fins (Fig. 3C).

\section{Discussion}

According to Mattei (1970) there are two basic types of teleost spermatozoa based on the process of nuclear rotation during spermiogenesis. In type I the nucleus rotates $90^{\circ}$ in relation to the flagellar axis, resulting in the flagellum being located perpendicular to the nuclear axis and the centrioles contained within a nuclear fossa. In type II, nuclear rotation does not occur, resulting in a flagellum located lateral to the nucleus and centrioles positioned outside any nuclear fossa. Another type of spermiogenesis, type III, was described by Quagio-Grassiotto \& Oliveira (2008), where the flagellum develops at a central position in relation to the nucleus, the nucleus does not rotate during spermiogenesis, and formation of a nuclear fossa and cytoplasmatic canal does not occur. Spermiogenesis type III is described for species of the family Pimelodidae (Quagio-Grassiotto \& Oliveira, 2008; Quagio-Grassiotto \& Carvalho, 2000), for some species of Callichthyidae e Loricariidae (Spadella, 2004), and for many species of the family Characidae (Baicere-Silva et al., 2011). Eigenmannia trilineata and the three Brachyhypopomus species analyzed all resemble type I spermatozoa, the most common type among Teleostei (Mattei, 1970), which is also observed in most species of Characiformes (QuagioGrassiotto et al., 2003; Burns et al., 2009), Cypriniformes (Bacceti et al., 1984; Burns et al., 2009) and Siluriformes (Poirer \& Nicholson, 1982; Burns et al., 2009) studied to date. The type I spermatozoon is presumed to be the primitive condition within Teleostei (Pecio, 2003). Gymnotus aff. carapo, on the other hand, produces spermatozoa more similar to Mattei's type II spermatozoon in that nuclear rotation does not occur during spermiogenesis resulting in a centriolar complex located outside any nuclear fossa. A similar spermatozoon has also been described in Gymnotus cf. anguillaris (França et al., 2007). Other ostariophysan spermatozoa similar to Mattei's type II have been reported in the characiform families Acestrorhynchidae and Lebiasinidae, and the incertae sedis species Bryconamericus stramineus Eigenmann, 1908 and in the siluriform family Callichthyidae (Burns et al., 2009). Given that all recent cladograms have ostariophysan species reporting "type II" spermatozoa nested within groups that produce type I spermatozoa, Burns et al. (2009) feel that ostariophysan "type II" spermatozoa may have arisen independently within this clade. Thus, the type II spermatozoa described in Perciformes by Mattei (1970) and the "type II" of ostariophysans appear to be examples of convergent evolution.

The shape, length, and width of the sperm cell nucleus may exhibit great variation among teleost species, with these characteristics frequently associated with the mode of fertilization. The basic structure of the spermatozoon of species that are externally fertilizing tends to be an anacrosomal aquasperm, defined as having a spherical to ovoid nucleus and a short midpiece (Jamieson, 1991). All species of gymnotiform fishes studied to date (Jamieson, 1991; França et al., 2007; França et al., 2009, Burns et al., 2009), as well as those in the present study, produce a type of anacrosomal aquasperm suggesting that these fishes engage in external fertilization. Although the representatives of the three families in the current study all exhibit similar sperm ultrastructure, some differences are evident, particularly with regard to the position of the flagellum relative to the nucleus, position of the centriolar complex, condensation of nuclear chromatin, presence and characteristics of vesicles, and the presence of flagellar fins.

The sperm nucleus of Eigenmannia trilineata possesses dense flocculent chromatin in a lighter matrix, similar to that described for Eigenmannia cf. virescens, Rhamphichthys cf. 


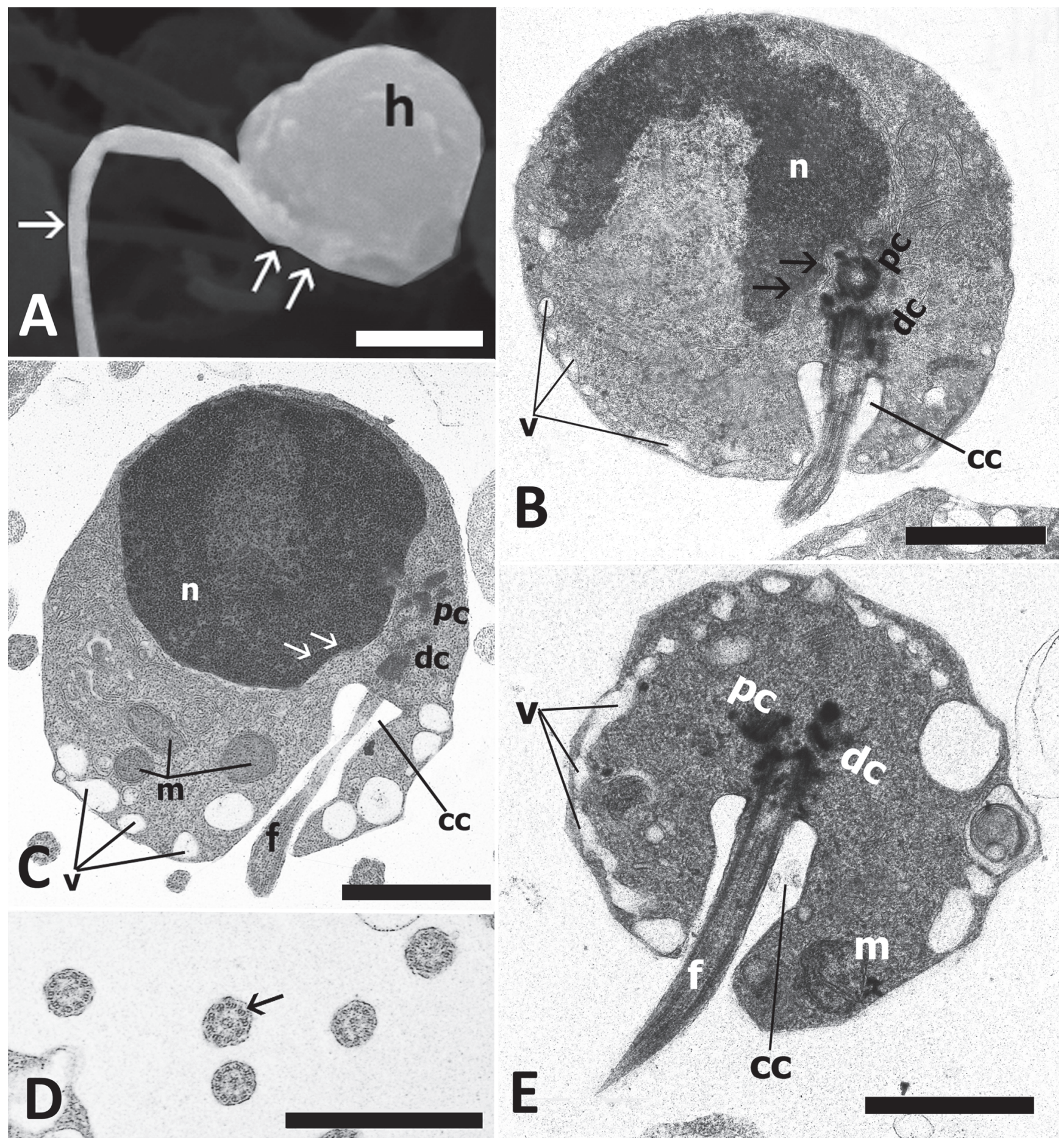

Fig. 2. A: Spermatozoon of Gymnotus aff. carapo $(\mathrm{SEM}), \mathrm{h}=$ sperm head, arrow $=$ flagellum, double arrow $=$ midpiece; B-C: Spermatozoa of $G$. aff. carapo in longitudinal section (TEM) showing spherical nucleus (n), centriolar complex and flagellum (f) lateral to the nucleus (n), double nuclear fossa (double arrow), centriolar arrangement ( $\mathrm{dc}=$ distal centriole, $\mathrm{pc}=$ proximal centriole), mitochondria (m), and presence of vesicles (v) in the posterior portion of midpiece, $\mathrm{cc}=$ cytoplasmic canal; D: Flagella of spermatozoa of $G$. aff. carapo in cross section (TEM) showing electron-lucent tubules of each peripheral doublet (arrow); E: Midpiece of spermatozoon of $G$. aff. carapo in longitudinal section (TEM) showing short cytoplasmatic canal (cc) and vesiclular arrangement $(\mathrm{v})$. Scale bars $=1 \mu \mathrm{m}$. 

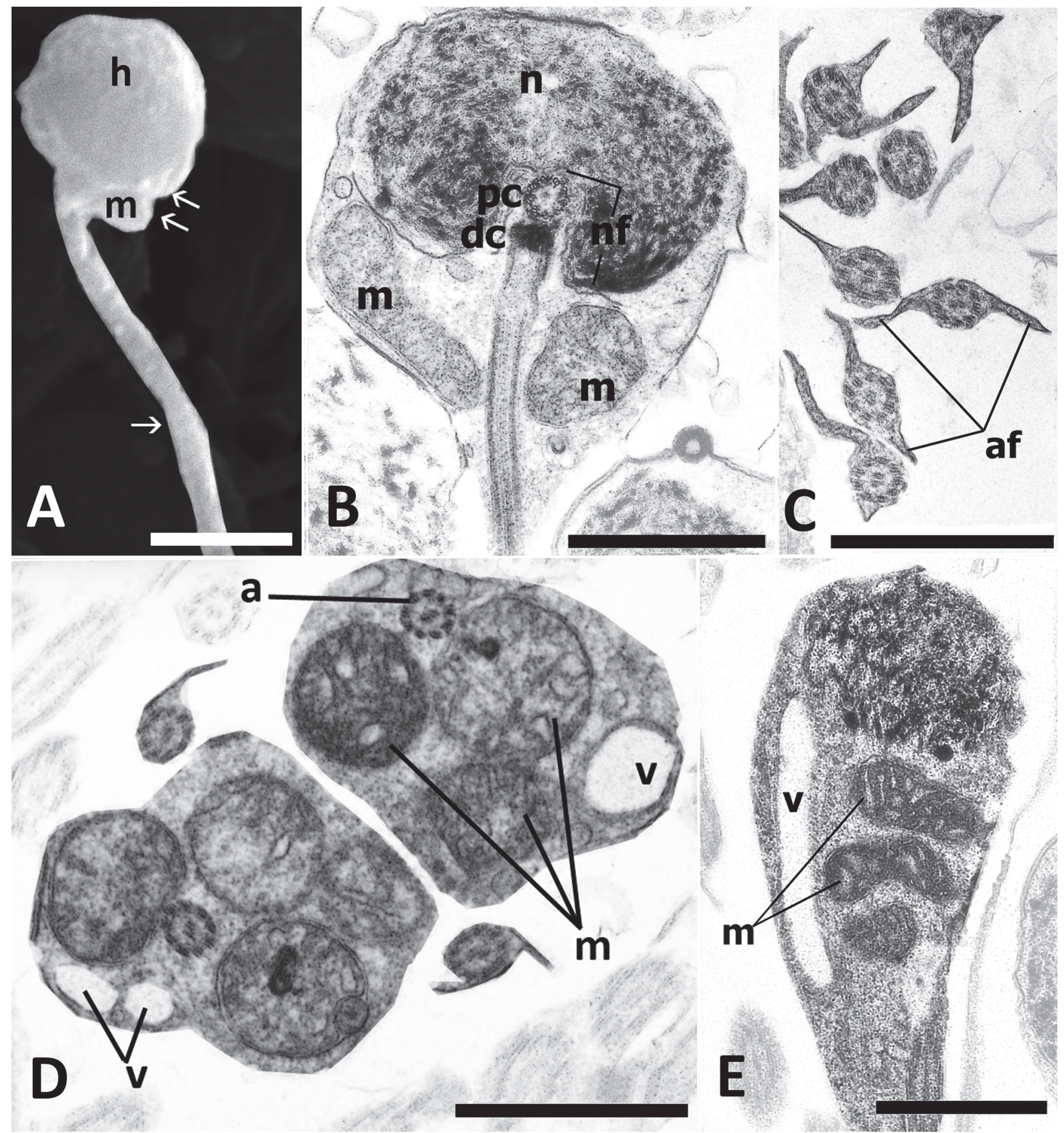

Fig. 3. A: Spermatozoon of Eigenmannia trilineata $(\mathrm{SEM}), \mathrm{h}=$ sperm head, arrow $=$ flagellum, double arrow $=$ midpiece, $\mathrm{m}=$ mitochondrion; B, E: Spermatozoa of E. trilineata in longitudinal section (TEM) showing ovoid nucleus (n) with flocculent chromatin, centriolar arrangement $(\mathrm{dc}=$ distal centriole, $\mathrm{pc}=$ proximal centriole $)$, and elongate mitochondria $(\mathrm{m}), \mathrm{v}=$ vesicles; $\mathbf{C}$ : Flagella of spermatozoa of E. trilineata in cross sections (TEM) showing axonemal or flagellar fins (af); D: Midpiece of spermatozoa of E. trilineata in cross section (TEM) showing presence of vesicles (v) and mitochondria (m), and flagellar axoneme (a) with electron-lucent tubules of each peripheral doublet. Scale bars $=1 \mu \mathrm{m}$. 
hahni, and Apteronotus cf. albifrons (França et al., 2009; Burns et al., 2009). On the other hand, nuclear chromatin is condensed and granular in the three species of Brachyhypopomus and Gymnotus aff. carapo, as reported for Brachyhypopomus cf. pinnicaudatus and Gymnotus cf. anguillaris (França et al., 2007; Burns et al., 2009). Of the three species of Brachyhypopomus in the present study, only B. gauderio has a deep, branching nuclear fossa similar to that described in Brachyhypopomus cf. pinnicaudatus (França et al., 2007; Burns et al., 2009). The extensive areas of lighter chromatin within the nucleus of $B$. bombilla may be unique to this species.

With the exception of Eigenmannia trilineata, abundant vesicles were observed within the midpieces of the other species analyzed, similar to that previously reported for conspecifics (Burns et al., 2009). Most of the vesicles of all the species herein analyzed contained some electron-dense material. It is possible that this material is the result of fixation artifact. However, the presence of such material in specimens fixed at different times and its consistent observation in the vesicles suggest that it may indeed be of cellular origin. Although numerous accessory microtubules have been reported in the spermatozoa of Gymnotus cf. anguillaris and Brachyhypopomus cf. pinnicaudatus (França et al., 2007; Burns et al., 2009), accessory microtubules were only observed in the midpiece of Gymnotus aff. carapo.

Prior to 2001, the presence of flagellar fins (axonemal fins) had not been reported for any taxon within Ostariophysi, and absence of such fins was interpreted as a secondary reduction and apomorphic character for this group of Teleostei (Jamieson, 1991). Since that time, Quagio-Grassioto et al. (2001) described fins on the flagellar membrane of Diplomystes mesembrinus [= Olivaichthys mesembrinus (Ringuelet, 1982)], considered to be a primitive representative of Siluriformes, and Pecio (2003) reported flagellar fins for the first time in a species of Characiformes. Within Gymnotiformes, flagellar fins have now been described in representatives of the families Rhamphichthyidae and Sternopygidae (França et al., 2009), being absent in species of Apteronotidae (França et al., 2009; Jamieson, 1991), Hypopomidae and Gymnotidae (França et al., 2007). In the present study, flagellar fins were only observed in E. trilineata, similar to the finding of França et al. (2009) for Eigenmannia cf. virescens. The greater amount of cytoplasm between the axoneme and flagellar plasma membrane observed in B. bombilla was also reported for Brachyhypopomus cf. pinnicaudatus (França et al., 2007; Burns et al., 2009).

This study demonstrates the diversity of sperm ultrastructural characters not only among the families of Gymnotiformes, but also within its individual genera. Such information may be useful in hypothesizing phylogenetic relationships at numerous taxonomic levels.

\section{Acknowledgements}

We are grateful to CAPES (PNPD 2282/09) and CNPq (process 476821/2003-7; 478002/2006-8) for the project support.

\section{Literature Cited}

Albert, J. S. \& W. G. R. Crampton. 2005. Diversity and Phylogeny of Neotropical eletric fishes (Gymnotiformes). Pp. 360-409. In: Bullock, T. E., C. D. Hopkins, A. N. Popper \& F. R. Fay (Eds.). Electroreception. Ithaca, Cornell University Press, 472p.

Alves-Gomes, J. A., G. Ortí, M. Haygood, W. Heiligenberg \& A. Meyer. 1995. Phylogenetic analysis of the evolution of the south american electric fishes (order Gymnotiformes) and the evolution of their electrogenic system: a sinthesis based on morphology, electrophysiology, and mitochondrial sequence data. Molecular Biology and Evolution, 12: 298-318.

Baccetti, B. 1987. News on Phylogenetic and Taxonomical Spermatology. Pp. 333-348. In: Mohri, H. (Ed.). New Horizons in Sperm Cell Research. Tokyo, Japan Scientific Societies Press/ New York, Gordon and Breach Science Publishers, 516p.

Baccetti, B., A. G. Burrini, G. Callaini, G. Gilbertini, M. Mazzinu \& S. Zerunian. 1984. Fish germinal cells. I. Comparative spermatology of seven cyprinid species. Gamete Research, 10: 373-396.

Baicere-Silva, C. M., K. M. Ferreira, L. R. Malabarba, R. C. Benine \& I. Quagio-Grassiotto. 2011. Spermatic characteristics and sperm evolution on the subfamily Stevardinae (Ostariophysi: Characiformes: Characidae). Neotropical Ichthyology, 9: 377-392.

Burns, J. R., S. H. Weitzman, K. R. Lange \& L. R. Malabarba. 1998. Sperm ultrastructure in characid fishes (Teleostei, Ostariophysi). Pp. 235-244. In: Malabarba L. R., R. E. Reis, R. P. Vari, Z. M. Lucena \& C. A. S. Lucena (Eds). Phylogeny and Classification of Neotropical fishes. Porto Alegre, Edipucrs, 603p.

Burns, J. R., A. D. Meisner, S. H. Weitzman \& L. R. Malabarba. 2002. Sperm and spermatozeugma ultrastructure in the inseminating catfish, Trachelyopterus lucenai (Ostariophysi: Siluriformes, Auchenipteridae). Copeia, 2002:173-179.

Burns, J. R., I. Quagio-Grassiotto \& B. G. M. Jamieson. 2009. Ultrastructure of spermatozoa:Ostariophysi. Pp. 287-388. In: Reproductive Biology and Phylogeny of Fishes (Agnathans and Bony Fishes). Enfield (NH, USA), Science Publishers, 788p.

Eschmeyer, W. N. \& J. D. Fong. 2011. Species of Fishes by family/ subfamily. Electronic Database accessible at http:// research.calacademy.org/redirect? url=http:// researcharchive.calacademy.org/research/Ichthyology/catalog/ fishcatmain.asp. Visited on November 2011.

França, G. F. 2006. Ultraestrutura da espermiogênese e dos espermatozóides da ordem Gymnotiformes (Teleostei, Ostariophysi) com considerações filogenéticas. Unpublished MsC. Thesis, Universidade Estadual de Campinas, Campinas, 89p.

França, G. F., C. Oliveira \& I. Quagio-Grassiotto. 2007. Ultrastructure of spermiogenesis and spermatozoa of Gymnotus cf. anguillaris and Brachyhypopomus cf. pinnicaudatus (Teleostei: Gymnotiformes). Tissue \& Cell, 39: 131-139.

França, G. F., C. Oliveira \& I. Quagio-Grassiotto. 2009. Spermatic cell characteristics in Gymnotiformes (Teleostei: Ostariophysi) and their phylogenetic meaning. Journal of Fish Biology, 75: 2226-2243.

Ito, S. \& M. J. Karnovsky. 1968. Formaldehyde glutaraldehyde fixatives containing trinitrus compounds. Journal of Cellular Biology, 36: 168.

Jamieson, B. G. M. 1991. Fish Evolution and Systematics: Evidence from Spermatozoa. Cambridge, Cambridge University Press, 319p.

Mago-Leccia, F. 1978. Los peces de la familia Sternopygidae de Venezuela. Acta Cientifica Venezolana, 29 (suppl. 1): 1-89.

Mago-Leccia, F. 1994. Electric fishes of the continental waters of America. Cracas, Clemente Editores, 207p. 
Mattei, X. 1970. Spermiogenése comparé des poisson. Pp. 57-72. In: Baccetti, B. (Ed.). Comparative Spermatology, New York, Academic Press, 169p.

Mattei, X. 1991. Spermatozoon ultrastructure and its systematic implication in fishes. Canadian Journal of Zoology, 69: 3038-3055.

Pecio, A. 2003. Spermiogenesis and fine structure of the spermatozoon in a headstander, Chilodus punctatus (Teleostei, Characiformes, Anostomidae). Folia Biologica, 51: 55-62.

Poirer, G. R. \& N. Nicholson. 1982. Fine structure of the testicular spermatozoa from the channel catfish, Ictalurus punctatus. Journal of Ultrastructure Research, 80: 104-110.

Quagio-Grassiotto, I. \& E. D. Carvalho. 2000. Ultrastructure of Sorubim lima (Teleostei, Siluriformes, Pimelodidae) spermiogenesis. Journal of Submicroscopic Cytology and Pathology, 32: 629-633.

Quagio-Grassiotto, I., C. Oliveira \& A. E. Gosztonyi. 2001. The ultrastructure of spermiogenesis and spermatozoa in Diplomystes mesembrinus. Journal of Fish Biology, 58: 1623-1632.

Quagio-Grassiotto, I., M. C. Gameiro, T. Schneider, L. R. Malabarba \& C. Oliveira. 2003. Spermiogenesis and spermatozoa ultrastructure in five species of the Curimatidae with some considerations on spermatozoal ultrastructure in the Characiformes. Neotropical Ichthyology, 1: 35-45.
Quagio-Grassiotto, I. \& C. Oliveira. 2008. Sperm ultrastructure and a new type of spermiogenesis in two species of Pimelodidae, with a comparative review of sperm ultrastructure in Siluriformes (Teleostei: Ostariophysi). Zoologischer Anzeiger, 247: 55-66.

Spadella, M. A. 2004. Estudo filogenético na Superfamília Loricarioidea (Teleostei: Siluriformes) com base na ultraestrutura dos espermatozóides. Unpublished MsC. Dissertation, Universidade Estadual de Campinas, 175p.

Triques, M. L. 1993. Filogenia dos gêneros de Gymnotiformes (Actinopterygii, Ostariophysi), com base em caracteres esqueléticos. Comunicações do Museu de Ciências da PUCRS, série Zoologia, 6: 85-130.

Submitted January 11, 2011

Accepted May 24, 2011

Published December 26, 2011 